\title{
ON THE LIFE HISTORY AND DEVELOPMENTAL STAGES OF THE MEDUSA PODOCORYNE BOREALIS
}

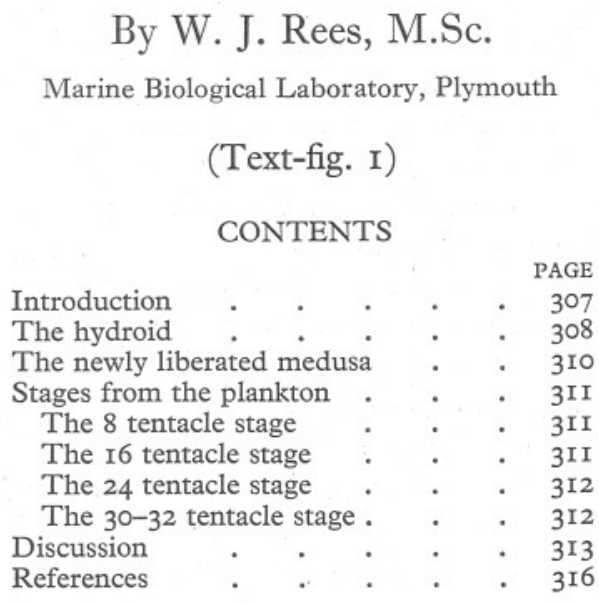

\section{INTRODUCTION}

It has been shown in a recent paper by Russell (1940) that in addition to Podocoryne carnea M. Sars, 1846 , and the so-called $P$. areolata, two other Podocoryne medusae, viz. P. hartlaubi Neppi \& Stiasny, I913, and P. minima (Trinci), also occur in the plankton in British waters. The identity of both hydroid and medusa of the European ${ }^{1} P$. carnea is well established and the medusa has never been known to mature with more than 8 tentacles (Kramp, I927; Russell, I940). P. minima is a small medusa with only 4 tentacles and need not be considered further in this paper.

As there were only two species of medusae of the genus Podocoryne previously known from British waters, it was generally assumed that the newly liberated medusa of the hydroid $P$. areolata (liberated with I6 tentacles) was the earliest stage of the medusa found in the plankton with $16-32$ tentacles. The discovery by Russell of a second species in the plankton (P. hartlaubi with 24-49 tentacles) indicated that the hydroid $P$. areolata might belong to either species.

While at Millport during I940 I obtained a fine series of all stages of the so-called $P$. areolata in the plankton. The earliest stage of the medusa has only 8 tentacles, so that it cannot belong to the hydroid $P$. areolata. As will be shown

1 The supposed occurrence of $P$. carnea in North American waters with more than 8 tentacles is discussed on p. 315 . 
below, the youngest stages may have been confused in the past with $P$. carnea. Kramp \& Damas (I925) have regarded the mature medusa as identical with Lymnorea borealis Mayer, I900. They have also re-examined the species described by Broch (1905) as Limnorea norvegica and identified it as P. areolata. Since this last specific name can no longer be used for this medusa, I propose to refer to the species as $P$. borealis. There is some evidence to suggest that a Podocoryne hydroid which I found in the Clyde belongs to this species.

The first certain records of this medusa from British waters are those of Browne (1895, I897) as ?Cytaeandra areolata from Port Erin and Valentia. Hartlaub (I9II) gives a full list of British and northern records of the medusa, but his records of the hydroid are those of $P$. areolata (Alder). Previous records of the medusa from Millport are given by Browne (1905), who states that in I9OI it occurred in April and July; in I902, young stages were found in March and adult medusae in May. During I940, young stages were found occasionally in the plankton from the beginning of March to the end of September, while the earliest mature medusae were present on 2 May. The young stages obtained throughout this period indicate that the hydroid is fertile during the spring, summer and autumn.

All the material of $P$. borealis was collected at Millport while I was holding a grant from the Royal Society. I wish to thank Dr Stanley Kemp, F.R.S., for facilities at Plymouth where the paper was completed.

\section{THE HYDROID}

A well-developed colony of a hydroid, which appeared to be identical with, and was at first thought to be, P. carnea, was found on a dead Buccinum shell dredged off the North End of Cumbrae on 6 March 1940. When found, all the polyps were large and particularly well developed as in mature colonies of Hydractinia echinata, and some of them bore medusa buds on the body of the hydranth. On the fertile polyps, which possessed 9-I4 filiform tentacles, there were from three to eight medusa buds. The polyps arose from a creeping network of stolons and there was no encrusting base or spines; the absence of the latter, however, might depend on the age of the colony. Medusae were liberated on the following day in the laboratory and these possessed better developed interradial tentacles than I had ever seen in specimens liberated from the true $P$. carnea. In all the young specimens liberated all 4 interradial tentacles were present. After many days of rearing the young medusae had developed no gonads on the stomach. Suspicions that this hydroid was distinct from $P$. carnea were confirmed when I found a complete series of twenty medusae, from the newly liberated to the sexually mature with 20-3I tentacles, in the plankton on 2 May I940 (see Table I). The youngest specimens were obviously newly liberated and agreed in all points with my specimens from the hydroid. The hydroid had been many days in captivity before it was realized that it was distinct from $P$. carnea, and by this 

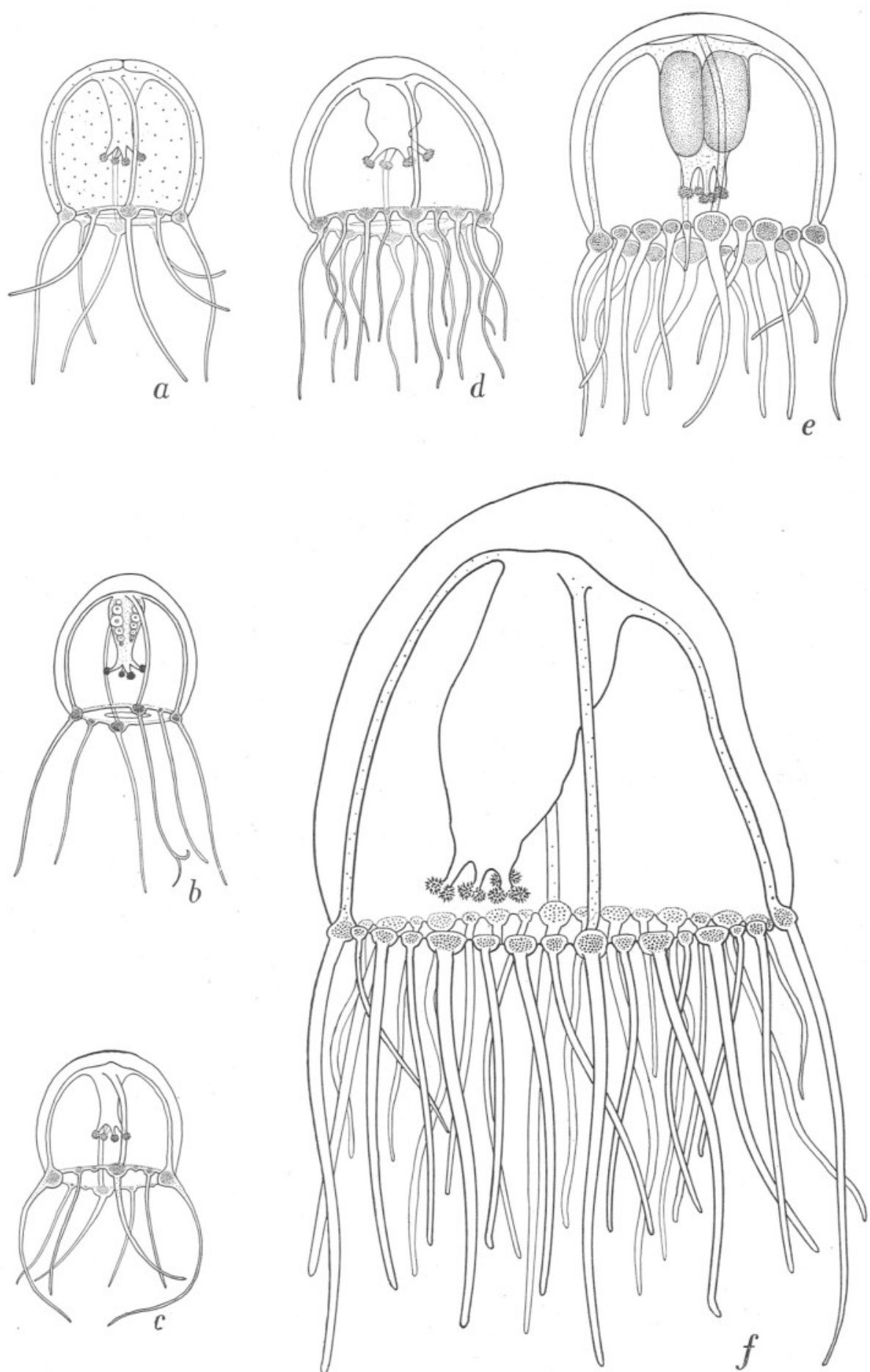

Fig. I. a, Podocoryne borealis; medusa newly liberated from the hydroid, Millport, 7. iii. 40. $b, P$. carnea; mature female medusa reared from the hydroid, Plymouth, 2. x. 36. c, $P$. borealis; medusa, 8 tentacle stage, Millport, 6. v. 40. d, P. borealis; medusa, I6 tentacle stage, Millport, 6. v. 40. e, P. borealis; medusa, with 17 tentacles, mature male, Millport, 6. v. 40. $f, P$. borealis; mature female medusa with 31 tentacles, Millport, 2. v. 40. 
time all the fertile and sterile polyps had become considerably reduced by the reproductive activity of the hydroid. A full description of the colony at this stage might give a misleading picture of the hydroid and it is hoped later to re-describe the species from fresh material.

\section{The Newly Liberated Medusa (Fig. I $a$ )}

Medusae newly liberated from the hydroid in the laboratory were $0.8-$ $\mathrm{I} \cdot 0 \mathrm{~mm}$. high and $0.9-\mathrm{I} \cdot 2 \mathrm{~mm}$. in diameter. They were of a deep. bell-shape with a uniformly thin umbrella with ex-umbrellar nematocysts and a welldeveloped velum. The stomach was tubular and in length about half the height of the sub-umbrellar cavity. There were four distinct mouth lips, each terminating in a knob of nematocysts. The radial canals were prominent and united around the margin by a ring canal. There were four large perradial tentacular bulbs, $0.1 \mathrm{~mm}$. in diameter, each with a well-developed tentacle. Interradially, there were four smaller bulbs each with a shorter tentacle than the perradial tentacle. The base of the stomach and the tentacle bulbs were of a brownish colour. Of twenty-eight medusae liberated from the hydroid described on p. 308, all possessed 8 tentacles, 4 of which, the perradial tentacles, were long and of equal length, while the interradial tentacles were a little shorter. There was no trace of gonad in any of the medusae even after many days of rearing.

These medusae may be compared with the newly liberated ones obtained from $P$. carnea which I found on a shell of Nassarius reticulatus dredged in Cawsand Bay, Plymouth, on I4 September 1936. Those liberated between 2I and 26 September differed but little in size, colour and the diameter of the tentacle bulbs from $P$. borealis, but there was considerable variation in the development and number of the interradial tentacles. Some possessed none. Browne (1896) also noticed the variation in the number of interradial tentacles and states that he did not see a specimen with 8 tentacles amongst those reared from the hydroid in his jar. Forty of the fifty-one specimens examined possessed immature gonads. The variation in the development of the interradial tentacles is tabulated below.

$\begin{array}{lccl} & \begin{array}{c}\text { No. of } \\ \text { medusae }\end{array} & \begin{array}{c}\text { No. of } \\ \text { perradial bulbs }\end{array} & \text { No. of interradial bulbs } \\ \text { 21. ix. 36 } & \text { I } & 4 & \text { 2 less developed, I rudiment } \\ \text { 23. ix. 36 } & \text { I } & 4 & 4 \text { less developed } \\ \text { 25. ix. 36 } & 7 & 4 & 4 \text { less developed } \\ \text { 26. ix. 36 } & \text { Io } & 4 & \text { None } \\ & \text { I0 } & 4 & \text { 2 less developed } \\ & \text { I0 } & 4 & \text { 2 fully and 2 less developed } \\ & \text { I2 } & 4 & 4 \text { fully developed }\end{array}$

A number of these were kept for rearing, and after a few days some of them became sexually mature (Fig. I $b$ ). The specimen figured matured in a few days with 4 perradial tentacles and 2 interradial tentacles. The perradial tentacular bulbs of this specimen had a diameter of $0.18 \mathrm{~mm}$. 


\section{Stages FROM THE PLANKTON}

The earliest stages from the plankton differed in no way from the medusae obtained in the laboratory and were $0.65-\mathrm{I} .0 \mathrm{~mm}$. high and $0.65-\mathrm{I} \cdot \mathrm{I} \mathrm{mm}$. in diameter. Here the tentacles are still unequal in length and may be referred to as $4+4$. In the descriptions below, the smallest tentacles are indicated in this way. Rudimentary bulbs from which no rudiment of a tentacle has developed are not included in the total. The succeeding stages can be roughly grouped into I6, 24 and 32 tentacle stages, but these are not very well defined. The tentacles themselves vary in length; for example, in the 8 tentacle stage described below, the interradial bulbs and tentacles are smaller than the perradial ones, while the rudimentary tentacular bulbs of an additional 8 tentacles are already appearing. Thus new tentacles are appearing even before those formed earlier reach full size. Even at the I6 tentacle stage and in older specimens the interradial tentacular bulbs have a slightly smaller diameter than the perradial bulbs. The differences in the sizes of the tentacular bulbs, however, do not appear to be as well marked as in P. hartlaubi.

\section{The 8 Tentacle Stage (Fig. I c)}

A medusa typical of this stage was captured on 6 May. The umbrella was $I \cdot I \mathrm{~mm}$. high and $I .2 \mathrm{~mm}$. in diameter. It had scattered nematocysts on the ex-umbrella. The stomach had a length of $0.8 \mathrm{~mm}$., reaching a little more than half-way to the margin of the bell. The mouth had four simple lips each terminating in a round cluster of nematocysts. There were 8 tentacles, the 4 interradial ones being well developed. The perradial and interradial tentacular bulbs had a diameter of 0.2 and $0.4 \mathrm{~mm}$. respectively. Eight additional bulbs were developing on the margin of the bell, but these were rudimentary bulbs without tentacles. All the bulbs were of a brownish colour. There was no trace of developing gonads. Kramp \& Damas (1925) describe a small specimen $\mathrm{I} .25 \mathrm{~mm}$. in height which appears to belong to this stage. It has 8 tentacles $(4+4)$ and 8 adradial tentacular rudiments. An apical canal was present and on account of this they regarded it as newly liberated. In my specimens an apical canal was rare, but when present it persisted for a long time. Kramp \& Damas also describe the oral lips as undivided in young examples.

\section{The I6 Tentacle Stage (Fig. I $d$ )}

I have many intermediate stages between the 8 tentacle stage and the I6 tentacle stage. It is at this latter stage that the rudiments of gonads begin to appear. The following description is of an immature female specimen obtained on 6 May (Fig. I $d$ ). The umbrella was $\mathrm{I} \cdot 7 \mathrm{~mm}$. high and $\mathrm{I} \cdot 8 \mathrm{~mm}$. in diameter. There were I6 tentacles, the perradial and interradial bulbs being much better developed than the adradial bulbs. The perradial, interradial and adradial bulbs had diameters of $0.28-0.3,0.2-0.22$ and $0.1 \mathrm{~mm}$. respectively. 
There were no rudimentary bulbs and the tentacles were more uniform in length than in many similar stages. The stomach was a little contracted and had a slight peduncle. The batteries of nematocysts on the four lips of the mouth were oval in shape, $0.08 \times 0.12 \mathrm{~mm}$.

Some medusae at this stage possess immature gonads and frequently become mature by the time a few more tentacles are added. Fig. $\mathrm{I} e$ is a drawing of a mature male medusa with $\mathrm{I} 7$ tentacles $(\mathrm{I} 6+\mathrm{I})$. The majority of the sexually mature specimens that I collected, however, possessed 20-24 tentacles, while a few large specimens had 30-32 tentacles.

A 16 tentacle stage has been figured by Browne (I897, Pl. xlviii, fig. I) as ?Cytaeandra areolata Haeckel. It is an earlier stage than Fig. I $e$ and is immature. The constriction at the base of the stomach in Browne's figure is more pronounced than in my specimens. Mayer (I9I0, Pl. I4, figs. 4, 5) figures two I6 tentacle stages similar to mine as $P$. carnea; there is no doubt that they belong to the present species.

\section{The 24 Tentacle Stage}

Mature and immature medusae were found at this stage and at intermediate stages between this and the 16 tentacle stage. In all the 24 tentacle stages found the mouth lips on the stomach were divided, possessing eight nematocyst knobs. An immature medusa belonging to this stage has been described and figured by Browne (1897, Pl. xlviii, fig. 2) from material obtained at Valentia, Co. Kerry. He also notes the occurrence of a female medusa with 24 tentacles and bearing ova on the stomach.

\section{The 30-32 Tentacle Stage (Fig. If)}

The biggest medusa caught in the series obtained on 2 May 1940 belonged to this stage. This specimen (Fig. I $f$ ) was a ripe female medusa having a height of $3.55 \mathrm{~mm}$. and a diameter of $4.0 \mathrm{~mm}$. The umbrella was thickened at the apex and gradually thinned towards the margin of the bell. There were $3 \mathrm{I}$ tentacles $(3 \mathrm{O}+\mathrm{I})$ and one tentacular bulb without a tentacle. The perradial, interradial, and adradial tentacles were better developed than later developed tentacles. The perradial, interradial and adradial tentacular bulbs had diameters of $0.35,0.28-0.3$ and $0.3 \mathrm{~mm}$. The tentacles, too, showed much variation in length. The radial canals had a diameter of o. $\mathrm{I} \mathrm{mm}$. The stomach was long and tubular, reaching nearly to the margin of the bell. The four mouth lips and the nematocyst knobs had become completely divided, so that there were eight distinct nematocyst knobs: in the preserved specimen as drawn the lips are contracted and do not show this well. These branched lips during life had the same appearance as those figured by Browne (1897, Pl. xlviii, fig. 2 ) in a specimen with 25 tentacles. In this and other well-developed specimens, the nematocysts formed a distinct continuous band along the edges of the lips from knob to knob. The nematocysts were of the spindle shape 
figured by Mayer (I9IO) and Allman (I87I-2). The four gonads were interradial in position and occupied the greater part of the length of the stomach and extending to meet each other in the perradii. The mature eggs on the interradii were dark and granular in appearance, while the more immature towards the edge of the gonad were transparent, giving, as Mayer states in his description of Lymnorea borealis, a reticulate appearance to the surface of the gonad. In the immature eggs the nuclei, each with a nucleolus, were plainly visible under the low power of the microscope.

The stomach, radial canals and ring canal were a delicate pinkish red in colour, while the endoderm of the tentacle bulbs was of a deep reddish-brown colour giving the living medusa a handsome appearance. During life, when the medusa was propelling itself through the water, the tentacles were frequently coiled in tight spirals.

Another mature stage with 29 tentacles, caught on 3 October 1940, had more fully branched oral lips which were twice dichotomously branched, so that there were sixteen nematocyst knobs. This is the condition figured by Mayer (I9I0, Pl. I5, figs. I-3) for Lymnorea borealis.

Additional data and measurements of a fine series of medusae caught in a single haul from Keppel Pier on 2 May 1940 are given in Table I. The youngest specimen was a newly liberated specimen, while all the specimens with more than 20 tentacles were sexually mature.

\section{Discussion}

The discovery of the various stages in the life history raises the question of what name the species should bear, since it can no longer be called Podocoryne areolata. Mayer stated his belief that the $P$. areolata of British waters might prove to be identical with his Lymnorea borealis. It is well known that the oral lips of the manubrium are branched in $P$. areolata, and it has been shown in this paper that the lips may branch in the larger specimens, so there is now no doubt that my species from Millport is identical with L. borealis. Mayer distinguished the genus Podocoryne from Lymnorea by its simple oral lips, but in this species the distinction only holds good for the youngest stages, and I have therefore referred the species to Podocoryne as P. borealis.

It will be seen from the foregoing description that three species are associated with the history of this species and may have been confused with it in the past. These are $P$. carnea $M$. Sars, $1846, P$. areolata (Alder, 1862) and $P$. hartlaubi Neppi \& Stiasny, I9I3.

The European P. carnea is well known and the first description of the hydroid and young medusa by Michael Sars undoubtedly refers to the species now generally recognized under that name, that is, with the medusa maturing with 8 tentacles. Lovén (I857) also recorded this medusa from Bohuslans in Norway and was able to obtain sexually mature medusae with 8 tentacles. Kramp (1927) states that 'no specimens of this medusa have ever been taken 
Table I. Podocoryne borealis (Mayer). Series of Medusae Caught at Keppel Pier, Millport, 2 May 1940. MEASUREMENTS IN MM.

\begin{tabular}{|c|c|c|}
\hline $\begin{array}{c}\text { Speci- } \\
\text { men } \\
\text { no. }\end{array}$ & $\begin{array}{l}\text { Dia- } \\
\text { meter }\end{array}$ & Height \\
\hline I & 0.85 & 0.95 \\
\hline 2 & $I \cdot 2$ & I. 5 \\
\hline 3 & I. 7 & $\mathrm{I} \cdot 45$ \\
\hline 4 & $I \cdot I$ & $I \cdot 3$ \\
\hline 5 & I. 7 & $\mathrm{I} \cdot 6$ \\
\hline 6 & I. 9 & $\mathrm{I} \cdot 6$ \\
\hline 7 & $2 \cdot 0$ & I. 6 \\
\hline 8 & $2 \cdot 2$ & $2 \cdot 3$ \\
\hline 9 & $2 \cdot I$ & $2 \cdot 0$ \\
\hline I0 & $2 \cdot I$ & $2 \cdot I$ \\
\hline I I & $2 \cdot I$ & I. 8 \\
\hline 12 & 2.15 & $2 \cdot 0$ \\
\hline I3 & $2 \cdot 6$ & $2 \cdot 15$ \\
\hline I4 & $2 \cdot 8$ & $2 \cdot 2$ \\
\hline 15 & $2 \cdot 65$ & $3 \cdot 0$ \\
\hline I6 & $2 \cdot 4$ & 2.0 \\
\hline 17 & 3.0 & $2 \cdot 7$ \\
\hline 18 & 3.0 & 3.0 \\
\hline I9 & $3 \cdot 4$ & $2 \cdot 6$ \\
\hline 20 & 4.0 & 3.55 \\
\hline
\end{tabular}

\begin{tabular}{|c|c|c|}
\hline $\begin{array}{l}\text { No. of } \\
\text { tentacles }\end{array}$ & $\begin{array}{l}\text { Length of } \\
\text { stomach }\end{array}$ & $\begin{array}{l}\text { of per- } \\
\text { radial } \\
\text { bulbs }\end{array}$ \\
\hline $\begin{array}{r}8(4+4) \\
16(8+8)\end{array}$ & $\begin{array}{l}0.4 \\
0.6\end{array}$ & $\begin{array}{l}0.13 \\
0.22\end{array}$ \\
\hline I6 $(8+8)$ & 0.8 & 0.2 \\
\hline I6 $(8+8)$ & $I \cdot O$ & 0.2 \\
\hline $16(12+4)$ & $I \cdot 2$ & 0.25 \\
\hline I6 $(8+8)$ & $I \cdot O$ & 0.26 \\
\hline I6 $(8+8)$ & I. 4 & 0.2 \\
\hline I6 $(8+8)$ & - & $0 \cdot 26$ \\
\hline I6 $(12+4)$ & I. 45 & 0.24 \\
\hline $19(16+3)$ & I.05 & 0.25 \\
\hline I6 & I. 45 & 0.3 \\
\hline I9 $(16+3)$ & $I \cdot 3$ & 0.25 \\
\hline $2 \mathrm{I}(\mathrm{I} 7+4)$ & - & 0.22 \\
\hline $20(16+4)$ & $I \cdot 3$ & 0.3 \\
\hline $20(16+4)$ & I. 5 & 0.33 \\
\hline $20(I 6+4)$ & $I \cdot 45$ & 0.25 \\
\hline $25(22+3)$ & $I \cdot 85$ & 0.32 \\
\hline $24(19+5)$ & $2 \cdot 2$ & 0.3 \\
\hline $26(22+4)$ & $\mathrm{I} \cdot 8$ & 0.3 \\
\hline $3 I(30+I)$ & 3.0 & 0.35 \\
\hline
\end{tabular}

\begin{tabular}{l}
\multicolumn{1}{c}{ Sex } \\
Z \\
Imm. male \\
Imm. female \\
Imm. male \\
Imm. male \\
Imm. male \\
Imm. female \\
Male \\
Imm. female \\
Male \\
Imm. female \\
Male \\
Male \\
Male \\
Male \\
Male \\
Female
\end{tabular}

No. of nematocyst knobs on oral lips

4 , round

4 , round

4 , round

4 , oval

4 , oval dividing

4, oval

-

4 , oval

4, all dividing

4,2 oval, 2 dividing

4,2 oval, 2 dividin

4 , all dividing

4 , all dividing

8 distinct knobs

8 distinct knobs

8 distinct knobs

8 distinct knobs

8 distinct knobs
Remarks

Newly liberated

Young specimen

Fairly young specimen

Stomach full

Stomach reaching bell margin

Gonads just appearing

Stomach reaching bell margin

Mouth and part stomach missing

Stomach nearly reaching margin

Stomach reaching half-way to margin

Stomach reaching bell margin

Gonads just appearing

The 4 small tentacles are very small

Gonads mature

Gonads mature

Gonads mature

Gonads mature

Gonads mature

Gonads mature 
in north European waters with more than eight marginal tentacles'. Russell (I940) makes a similar statement. There is, however, a very doubtful record of a specimen with I6 tentacles from Trieste by Graeffe (I884). Mayer (I9I0) has described P. carnea from North American waters maturing with 8, I6, 24 or 32 tentacles, and because of the numerous tentacles has referred to his species as $P$. carnea var. americana.

If we were to accept the view that Mayer was dealing with a single species, then my specimens from the Clyde would have to be referred to $P$. carnea, and we would expect to find mature medusae with I0, I2, I4 or I5 tentacles in the plankton. However, none has ever been recorded in north European waters and we are left with the view that there are two separate species-one medusa maturing with 8 tentacles and the other maturing with 16-32 tentacles. The close similarity of the two hydroids and an apparently continuous series of mature medusae at the $8, I 6,24$ and 32 tentacle stages may have led Mayer to assume that he was dealing with a single species. There is nothing in Mayer's account to suggest that he obtained mature medusae at intermediate stages between the 8 and I6 tentacle stages. A careful study of Mayer's description of the hydroid shows that in all probability he was dealing with two distinct species-one of which was identical with the European P. carnea (Mayer, I9IO, text-fig. 74) and the other was P. borealis (Pl. I4, fig. 2). $\mathrm{He}$ states that 'the reproductive polypites, or gonostyles, are frequently exactly similar in size and shape to the feeding-polypites, and, in fact, are probably merely feeding-polypites which have developed medusa buds (see Pl. I4, fig. 2, g). In other instances the gonostyles are smaller and more slender, and possess not more than 4 to 8 tentacles.' In the hydroids of $P$. carnea which I have been able to collect at Plymouth the reproductive polyps have always been small with only 4 or 5 tentacles. In the hydroid from Millport, however, the reproductive polyps were as large as the sterile ones and only later diminished in size after liberating numerous medusae. Allman (I87I-2) and Hincks (I868) have probably described the two species under the name $P$. carnea, and a careful redescription of both hydroids from ample material is much to be desired. It is thus clear that some at least of the records of the hydroid and young medusa of $P$. carnea are records of $P$. borealis.

The hydroid $P$. areolata (Alder) may be distinguished from other known British species of the genus by the irregular grouping of the chitinous spines on the basal crust and by the position of the medusa buds; these are sessile on the encrusting base. Further, when the medusa is liberated it has 4 large perradial tentacles and I2 smaller intermediate ones, making a total of I6 tentacles. It is, perhaps, because this species has always been associated with the medusa $P$. borealis in British waters that all hydroids of this kind in which the medusa buds originate on the body of the polyps have been assigned to $P$. carnea. Russell (I940) has suggested that $P$. hartlaubi may be the medusa of Alder's species.

Russell has also indicated that there is a possibility that $P$. hartlaubi may 
have been previously recorded from British waters as 'Podocoryne areolata' because of its superficial similarity to that medusa.

It is suggested that the synonymy of $P$. borealis and $P$. areolata becomes:

Podocoryne areolata (Alder, I862):

Hydractinia areolata, Alder, 1862.

Rhizocline areolata, Allman, I864.

Podocoryne areolata, Hincks, I868.

Cytaeandra areolata, Haeckel, I879.

Podocoryne borealis (Mayer, I900):

Cytaeandra areolata, Browne, 1895.

?Cytaeandra areolata, Browne, I897.

Podocoryne areolata, Mayer, I9I0; Hartlaub, I9II (medusa only).

Lymnorea borealis, Mayer, I900.

Limnorea norvegica, Broch, I905.

\section{REFERENCES}

ALDER, J., I862. Supplement to a catalogue of the zoophytes of Northumberland and Durham. Trans. Tyneside Nat. Field Club, Vol. v, Pt. III, pp. 225-47.

Allman, G. J., I864. On the construction and limitation of genera among the $\mathrm{Hy}-$ droida. Ann. Mag. Nat. Hist., Ser. 3, Vol. xIII, pp. 345-80.

- I871-2. A Monograph of the Gymnoblastic or Tubularian Hydroids, pp. I-450. Ray Society.

Broch, H., I905. Zur Medusenfauna von Norwegen. Bergens Museum Aarbog, I905, No. II, pp. I-8.

BRowne, E. T., I895. Report on the medusae of the L.M.B.C. District (Isle of Man). Trans. Liverpool Biol. Soc., Vol. Ix, pp. 243-86.

- I896. On British hydroids and medusae. Proc. Zool. Soc. London, pp. 459-500.

- 1897. On British Medusae. Proc. Zool. Soc. London, pp. 816-35.

GraefFe, E., I884. Übersicht der Seethierfauna des Golfes von Trieste. III. Coelenteraten. Arb. Zool. Inst. Wien, Vol. v, pp. 333-62.

HaECKel, E., I879. Das System der Medusen, pp. I-672.

Hartlaub, C., I9I I. Nordisches Plankton. Lief. 6, xiI, Craspedote Medusen. Teil I, Lief. 2, Familiae III, Margelidae, pp. I37-235.

Hincks, T., I868. A History of the British Hydroid Zoophytes, pp. I-338. London: John van Voorst.

Kramp, P. L., I927. The Hydromedusae of Danish waters. Mem. Acad. Sci. Lett. Danemark, Sect. Sci., Ser. 8, Tome xII, no. I, pp. I-290.

Kramp, P. L. \& Damas, D., 1925. Les Méduses de la Norvège. Vidensk. Medd. Dansk. naturh. Foren. Køjb., Bd. 80, pp. 217-324.

LovÉN, C., 1857. Till utvecklingen af Hydractinia. Öfvers af K. Vet.-Akad. Förh., I857.

Mayer, A. G., I900. Some medusae from Tortugas, Florida. Bull. Mus. Comp. Zoöl. Harvard, Vol. xxxviI, no. 2, pp. I3-82.

- I9Io. Medusae of the World, Vol. I, Hydromedusae, pp. I-230.

Neppi, Valeria \& Stiasny, G., I9I3. Die Hydromedusen des Golfes von Trieste. Arb. Zool. Inst. Univ. Wien u. Zool. Stat. Trieste, Bd. xx, pp. 23-90.

Russell, F. S., I940. On some medusae of the genera Podocoryne and Phialopsis. Fourn. Mar. Biol. Assoc., Vol. xxrv, pp. 525-31.

Sars, M., I846. Fauna Littoralis Norvegiae, Vol. I, pp. I-94. Christiania. 